\title{
Wybrane zagadnienia wpływu procesów tribologicznych w środkach transportu drogowego na stan środowiska
}

\author{
Andrzej Kulczycki ${ }^{{ }^{*}}$, Urszula Kaźmierczak ${ }^{2}$, Jarosław Kałużny ${ }^{3}$, Wojciech Dzięgielewski ${ }^{2}$ \\ ${ }^{1}$ Wydział Filozofii Chrześcijańskiej, Uniwersytet Kardynała Stefana Wyszyńskiego ul. Wóycickiego 1/3, 01-938 Warszawa \\ ${ }^{2}$ Instytut Techniczny Wojsk Lotniczych, ul. Księcia Bolesława 6, 01-494 Warszawa \\ ${ }^{3}$ Wydział Inżynierii Transportu, Politechnika Poznańska, ul. Piotrowo 2, 61-138 Poznań \\ *a.kulczycki@uksw.edu.pl
}

\begin{abstract}
Streszczenie
Artykuł poświęcony jest zagadnieniom uciążliwości transportu samochodowego dla środowiska. Problematyka ta omówiona jest w kontekście procesów tribologicznych, których efektem jest zwiększone zużycie paliwa i w konsekwencji zwiększona emisja składników gazów spalinowych. Na podstawie danych literaturowych określono udział oporów tarcia w poszczególnych zespołach samochodów osobowych, ciężarowych i autobusów w sumarycznej konsumpcji paliwa. Wykorzystując dane statystyczne dla Polski określono wpływ procesów tarcia w poszczególnych grupach pojazdów na roczną emisję $\mathrm{CO}_{2}$ ze środków transportu. W końcowej części artykułu przedstawiono wyniki wstępnych badań nad możliwością obniżania oporów tarcia w różnych węzłach tarcia występujących w pojazdach samochodowych przez wprowadzenie do olejów smarowych nanomateriałów węglowych.
\end{abstract}

\section{Słowa kluczowe}

transport, paliwa, spaliny, tarcie

\section{Wstęp}

Jednym z podstawowych problemów ochrony środowiska jest redukcja emisji gazów cieplarnianych (GHG), jak również innych zanieczyszczeń, głównie powietrza atmosferycznego przez maszyny i urządzenia stanowiące podstawę współczesnej cywilizacji technicznej. Funkcjonowanie maszyn i urządzeń uzależnione jest od energii, która musi być do nich doprowadzona, w znacznej większości do ich elementów ruchomych. Zanieczyszczenie środowiska wiązane jest zwykle z przetwarzaniem dostarczanej do maszyn i urządzeń energii na formy energii potrzebne dla ich funkcjonowania. Źródłami energii są w przeważającej mierze paliwa - naturalnie występujące substancje organiczne o skumulowanej w wiązaniach chemicznych energii. Skumulowana w nich energia zamieniana jest na ciepło, które następnie zamieniane jest na energię kinetyczną ruchomych elementów maszyn i urządzeń. Urządzeniami służącymi do przekształcenia zmagazynowanej w paliwach energii na ciepło są piece, a w przypadku dalszej zamiany ciepła w energię kinetyczną silniki. Zamiana ciepła w energię kinetyczną może odbywać się 
bezpośrednio - silniki spalania wewnętrznego lub pośrednio - silniki spalania zewnętrznego lub zamiana ciepła na energię elektryczną, a następnie energii elektrycznej w energię kinetyczną (silniki elektryczne).

Gwałtowny wzrost liczby ludności i towarzyszący temu wzrost liczby użytkowanych maszyn i urządzeń, w tym środków transportu, powoduje proporcjonalny wzrost zużycia paliw, a w konsekwencji emisji GHG i innych zanieczyszczeń powietrza atmosferycznego. Zauważona w ostatnich dekadach konieczność:

- w skali globalnej - redukcji emisji GHG

- w skali lokalnej (aglomeracje miejskie, szlaki komunikacyjne) redukcji emisji innych zanieczyszczeń powietrza

spowodowała intensywne działania ośrodków naukowych i przemysłowych ośrodków badawczych nakierowane na wzrost efektywności wykorzystania energii. Jednym z obszarów badań jest minimalizacja strat energii na pokonanie oporów tarcia ruchomych elementów maszyn i urządzeń.

\section{Ogólne informacje o tarciu i smarowaniu}

Tarcie jest jednym z procesów fizycznych powszechnie występujących w przyrodzie, $\mathrm{w}$ tym $\mathrm{w}$ procesach technologicznych i eksploatacji maszyn i urządzeń. Tarciem nazywana jest całość zjawisk fizycznych towarzyszących przemieszczaniu się względem siebie dwóch ciał (tarcie zewnętrzne) lub elementów tego samego ciała (tarcie wewnętrzne), które powodują rozpraszanie energii podczas ruchu. Rozpraszanie energii jest przekazywaniem jej do środowiska, głównie na sposób ciepła. Ilość ciepła oddawanego do otoczenia na skutek tarcia zależna jest w znacznym stopniu od rodzaju tarcia, w tym od wielkości współczynnika tarcia $\mu$. Współczynnik tarcia dla tarcia ślizgowego jest wyrażany, jako stosunek siły tarcia i siły docisku współpracujących elementów węzła tarcia. Jest to wielkość bezwymiarowa, określająca, w jakim stopniu względny ruch elementów maszyn i urządzeń hamowany jest przez tarcie.

$$
\mu=F / P
$$

W przypadku tarcia tocznego współczynnik tarcia wyrażany jest, jako stosunek momentu tarcia tocznego $M_{t}$ do siły nacisku $N$. Współczynnik ten ma wymiar wyrażany w jednostkach długości (np. mm).

$$
\mathrm{f}=\mathrm{M}_{\mathrm{t}} / \mathrm{N}
$$

Opory tarcia tocznego są zwykle mniejsze niż tarcia ślizgowego. Stąd dążenie konstruktorów urządzeń do eliminacji tarcia ślizgowego tam gdzie jest to możliwe. Tarcie ślizgowe może być zastą̧ione tocznym w niektórych łożyskach - zastąpienie łożysk ślizgowych tocznymi. W silnikach spalinowych i przekładniach zębatych nie można jednak wyeliminować tarcia ślizgowego, np. w układzie tłok - cylinder oraz w przekładniach zębatych, gdzie występuje tarcie toczne z poślizgiem. Nie zawsze eliminacja tarcia ślizgowego jest również celowa. Łożyska toczne, poddawane dużemu naciskowi mogą po relatywnie krótkim czasie ulegać zużyciu zmęczeniowemu - pittingowi lub mikropittingowi, co prowadzi do konieczności wymiany łożysk. Miejsca występowania tarcia w pojeździe samochodowym, ze wskazaniem rodzaju tarcia to:

- silnik: tarcie ślizgowe oraz tarcie toczne (łożyska toczne) ze smarowaniem olejem silnikowym;

- skrzynia biegów: tarcie toczne z poślizgiem (przekładnie zębate) oraz tarcie toczne (łożyska toczne) ze smarowaniem olejem przekładniowym;

- opony samochodowe: tarcie toczne z poślizgiem;

- tarcza hamulcowa - kocki: tarcie ślizgowe techniczne suche;

- łożyska toczne: tarcie toczne, smarowanie smarem plastycznym.

Opory tarcia są jednym z dwóch podstawowych skutków tarcia. Drugim skutkiem jest usuwanie materiału powierzchni współpracujących elementów maszyn - zużycie. Prowadzi ono do zmiany wymiarów współpracujących elementów, co zwykle skutkuje pogorszeniem stanu technicznego pojazdu, a w wielu przypadkach zwiększeniem 
negatywnego wpływu użytkowania pojazdu na środowisko.

Zmniejszenie oporów tarcia i ograniczenie szybkości zużywania współpracujących części pojazdów samochodowych może być osiągnięte przez stosowanie odpowiednio dobranych środków smarowych - olejów smarowych i smarów plastycznych. Są to substancje ciekłe lub smary plastyczne układy koloidalne, które rozdzielają powierzchnie współpracujących elementów węzłów tarcia. Rozdzielenie to prowadzi do przeniesienia tarcia do warstwy środka smarnego, co powoduje znaczne obniżenie oporów tarcia oraz znaczące zmniejszenie szybkości zużywania współpracujących elementów węzła tarcia.

Stosowane w pojazdach samochodowych podstawowe środki smarowe to:

- olej silnikowy smarujący następujące tzw. pary trące: tłok i pierścienie tłokowe - cylinder, łożyska wału korbowego, elementy układu sterowania zaworami

- olej przekładniowy smarujący przekładnie zębate oraz łożyska skrzyni biegów i mechanizmu różnicowego

- smar plastyczny smarujący łożyska toczne na piastach kół pojazdu

\section{Systematyka procesów tribologicznych w relacji do środowiska naturalnego}

Procesy tribologiczne systematyzowane są przy zastosowaniu różnych kryteriów. Jednym z częściej stosowanych jest podział procesów tribologicznych ze względu na rodzaj tarcia: tarcie suche, techniczne suche, tarcie / smarowanie graniczne, tarcie / smarowanie elastohydrodynamiczne, tarcie / smarowanie hydrodynamiczne. W niniejszym artykule zaproponowano systematykę procesów tribologicznych, w której jako kryterium przyjęto skutki tarcia, mające wpływ na zanieczyszczenie środowiska naturalnego. Według tego kryterium procesy tribologiczne podzielono na: generujące bezpośrednie skutki środowiskowe oraz generujące pośrednie skutki środowiskowe.

\subsection{Procesy generujące bezpośrednie skutki środowiskowe}

Bezpośrednie skutki procesów tribologicznych zachodzących w pojazdach samochodowych są rezultatem:

- oporów tarcia w silniku, skrzyni biegów i układzie napędowym, łożysk piast kół, a także toczenia się opon po nawierzchni, na pokonanie których potrzebna jest praca wykonywana dzięki spaleniu odpowiedniej ilości paliwa - większa ilość spalonego paliwa związana jest $\mathrm{z}$ większą emisją do powietrza atmosferycznego składników spalin, w tym $\mathrm{CO}_{2}$,

- zużywania klocków i tarcz hamulcowych oraz opon samochodowych - emisja pyłów do powietrza atmosferycznego,

- emisja ciepła powstałego w wyniku tarcia suchego podczas hamowania (istotne zwłaszcza w ruchu miejskim)

\subsection{Procesy generujące pośrednie skutki środowiskowe}

Pośrednie skutki procesów tribologicznych związane są ze zużywaniem smarowanych elementów środków transportu. Zużycie elementów węzłów tarcia prowadzi do pogorszenia stanu technicznego pojazdu. Szczególnie ważne jest zużycie elementów układu: tłok i pierścienie tłokowe - cylinder oraz zużycie aparatury wtryskowej - nadmierna emisja niespalonych węglowodorów $\left(\mathrm{C}_{\mathrm{x}} \mathrm{H}_{\mathrm{y}}\right)$ oraz cząstek stałych (PM).

Zużycie pierścieni tłokowych prowadzi do zmiany ich wymiarów, a w konsekwencji do zmniejszenia szczelności układu tłok - cylinder. Rozszczelnienie tego układu prowadzi do spadku mocy silnika - uzyskanie tego samego przyspieszenia pojazdu wymaga spalenia większej ilości paliwa, a w konsekwencji wyemitowania większej ilości składników spalin.

Zużycie pierścieni zgarniających prowadzi do ograniczania efektywności usuwania oleju silnikowego z powierzchni cylindra przy ruchu tłoka. W rezultacie na powierzchni cylindra pozostaje olej 
silnikowy, który ulega niezupełnemu spaleniu. Prowadzi to do wzrostu emisji niespalonych węglowodorów $\left(\mathrm{C}_{\mathrm{x}} \mathrm{H}_{\mathrm{y}}\right)$ oraz cząstek stałych (PM).

Zużycie elementu pojazdu, gdy przekroczy dopuszczalną wielkość powoduje konieczność dokonania naprawy lub remontu pojazdu. Naprawa i remont są czynnościami, na których wykonanie potrzebna jest energia. Najczęściej jest to energia elektryczna. Jej pozyskanie skutkuje emisją zanieczyszczeń powietrza atmosferycznego - emisja $\mathrm{CO}_{2}, \mathrm{CO}, \mathrm{NO}_{\mathrm{x}}$ i PM. (powstają ponadto odpady).

Kolejnym pośrednim skutkiem tarcia jest gospodarka tzw. olejami przepracowanymi lub zużytymi. Oleje smarowe moga być stosowane do smarowania elementów pojazdów tylko przez pewien czas, po którym muszą być wymienione na oleje świeże. Oleje zużyte są odpadami niebezpiecznymi, zwierają metale i węglowodory aromatyczne. Przedostanie się ich do środowiska stanowi zagrożenie dla gleb i wód. Rozwinięty i upowszechniony w ostatnich dekadach system serwisowania pojazdów oraz system zbiórki i regeneracji olejów zużytych zminimalizował to zagrożenie.

\section{Skutki procesów tribologicznych w środkach transportu dla środowiska naturalnego}

Tarcie powoduje hamowanie ruchu elementów silników pojazdów: tłoków względem cylindrów, łożysk, pomp paliwa ciekłego i oleju silnikowego oraz elementów pozostałego oprzyrządowania. Tarcie jest przyczyną hamowania ruchu elementów przekładni zębatych i łożysk w skrzyniach biegów i w układach napędowych. Na Rys. 1 i 2 przedstawiono szacunkowe udziały tarcia w bilansie energii samochodu osobowego.

Jak to przedstawiono na powyższych rysunkach straty paliwa na pokonanie oporów tarcia elementów silników i układu napędowego najmniejsze są w przypadku samochodów osobowych, największe w samochodach ciężarowych.
Zużywanie paliwa na pokonanie oporów tarcia ruchomych elementów pojazdów samochodowych powiązano z emisją $\mathrm{CO}_{2}$ przypisaną do transportu drogowego. Poniżej przedstawiono bilans emisji $\mathrm{CO}_{2}$ dla Polski, która pod względem struktury pojazdów użytkowanych w transporcie nie odbiega od struktury w innych krajach europejskich.

Jak wynika z tabeli 1 niemal 30\% emisji $\mathrm{CO}_{2}$ ze środków transportu drogowego spowodowane jest pokonywaniem oporów tarcia elementów silnika, skrzyni biegów i pozostałych elementów pojazdów samochodowych, w których występuje tarcie. Łączna emisja $\mathrm{CO}_{2}$ dla Polski w 2012 roku wynosiła $286,2 \mathrm{mln}$ ton (Kacperczyk, Rzymek 2015). Emisja $\mathrm{CO}_{2}$ związania z użytkowaniem samochodów osobowych, ciężarowych i autobusów stanowi około $13 \%$ całkowitej, krajowej emisji $\mathrm{CO}_{2}$, a emisja związana z pokonywaniem oporów tarcia w środkach transportu stanowi około $4 \%$ całkowitej krajowej emisji $\mathrm{CO}_{2}$.

Emisja gazów cieplarnianych, głównie $\mathrm{CO}_{2}$ jest problemem globalnym. Na szczeblu lokalnym - aglomeracje miejskie, szlaki komunikacyjne, równie ważna jest emisja pozostałych składników spalin. Zużycie paliw na pokonanie oporów tarcia w urządzeniach wchodzących w skład pojazdów samochodowych powoduje wzrost emisji $\mathrm{CO}, \mathrm{NO}_{x}$, WWA i PM. Zanieczyszczenie powietrza atmosferycznego tymi substancjami wpływa na jakość środowiska w aglomeracjach miejskich i w pobliżu szlaków komunikacyjnych. Jednym z bardziej znaczących dla zdrowia ludzi jest zanieczyszczenie powietrza atmosferycznego węglowodorami aromatycznymi, głównie wielopierścieniowymi węglowodorami aromatycznymi WWA.

Krajowa całkowita emisja WWA w 2012 roku wynosiła $43511 \mathrm{~kg}$, w tym transport drogowy odpowiedzialny był za wprowadzenie 2657 kg WWA. Przyjmując, że energia uzyskana z około 30\% spalonego w silnikach pojazdów samochodowych paliwa potrzebna jest na pokonanie oporów tarcia, spalenie tej ilości paliw spowodowało w 2012 


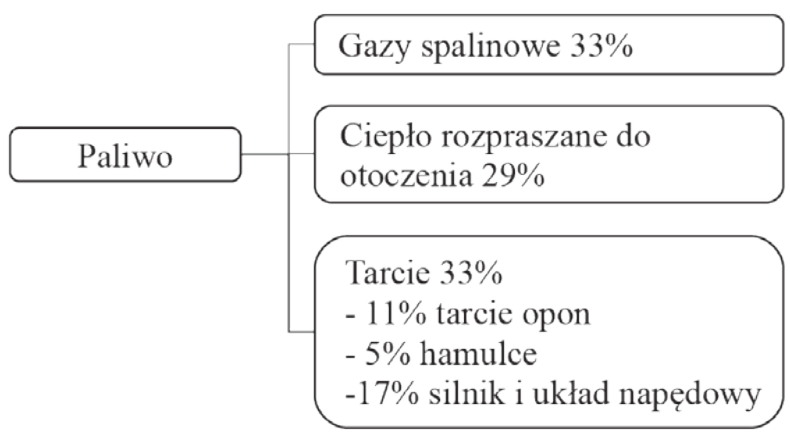

Rys. 1. Opory tarcia w samochodzie osobowym. Straty energii wprowadzanej z paliwem dla samochodu osobowego (Holmberg et al.2012)

A) Roczny bilans energii autobusu komunikacji miejskiej ( $80000 \mathrm{~km} / \mathrm{rok})$

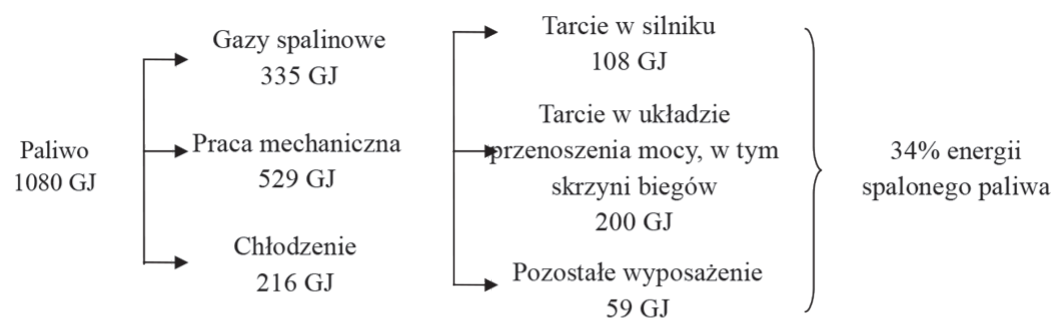

B) Roczny bilans energii samochodu ciężarowego z naczepą (100000 km/rok)

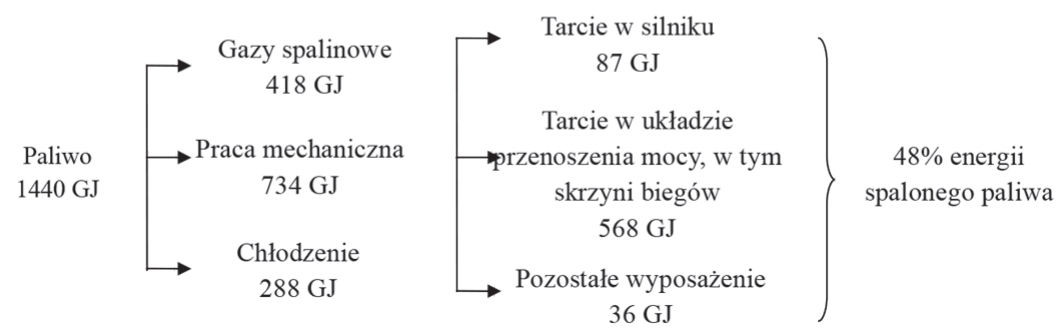

Rys. 2. Roczny bilans strat energii na skutek tarcia a) dla autobusu komunikacji miejskiej, b) dla samochodu ciężarowego z naczepą (Holmberg et al. 2014)

Tabela 1. Bilans emisji $\mathrm{CO}_{2}$ przez transport drogowy w Polsce w 2012 roku na podstawie danych statystycznych GUS

\begin{tabular}{lcccc}
\hline $\begin{array}{c}\text { Grupa pojazdów } \\
\text { samochodowych }\end{array}$ & $\begin{array}{c}\text { Roczna emisja } \mathrm{CO}_{2} \\
\text { [mln. ton] }\end{array}$ & $\begin{array}{c}\text { Strata energii paliwa } \\
\text { na pokonanie } \\
\text { oporów tarcia } \\
\text { [w proc.] }\end{array}$ & $\begin{array}{c}\text { Roczna emisja } \mathrm{CO}_{2} \text { związana } \\
\text { z pokonywaniem oporów } \\
\text { tarcia w środkach transportu } \\
\text { [mln. ton] }\end{array}$ & $\begin{array}{c}\text { Emisja } \mathrm{CO}_{2} \text { związana } \\
\text { z pokonywaniem } \\
\text { oporów tarcia } \\
\text { [w proc.] }\end{array}$ \\
\hline Samochody osobowe & 22,5 & 17 & 3,8 & - \\
Samochody ciężarowe & 13,0 & 48 & 6,2 & - \\
Autobusy & 2,0 & 34 & 0,7 & - \\
Łącznie & 37,5 & - & 10,7 & 28,5 \\
\hline
\end{tabular}


roku emisję około $800 \mathrm{~kg}$ WWA, co stanowi około $2 \%$ całkowitej rocznej krajowej emisji.

Powyższe dane wskazują, że procesy tribologiczne zachodzące w urządzeniach środków transportu samochodowego odpowiedzialne są za emisje składników gazów spalinowych w stopniu nie pozwalającym na ich pominięcie.

\section{Możliwości redukcji emisji zanieczyszczeń środowiska wywołanej procesami tribologicznymi}

Przedstawiony wyżej znaczący wpływ oporów tarcia na zużycie paliwa przez środki transportu spowodował już wiele lat temu zainteresowanie możliwością redukcji oporów tarcia. Zainteresowanie to spowodowane było głównie względami ekonomicznymi - obniżenie kosztów eksploatacji środków transportu. W latach 9o-tych ubiegłego wieku wiele firm spoza branży rafineryjnej oferowało dodatki do olejów smarowych, głównie silnikowych, które miały obniżać opory tarcia. Ich działanie było różne, w większości polegać miało na tworzeniu na powierzchni smarowanych elementów urządzeń warstwy, dla której współczynnik tarcia jest niższy, niż np. dla powierzchni stalowych. Wprowadzanie tego rodzaju dodatków, np. zawierających rozdrobniony teflon (w postaci zawiesiny), w niektórych testach, nawet silnikowych rzeczywiście powodowało obniżenie oporów tarcia. Ich stosowanie w eksploatowanych pojazdach nie zdało jednak egzaminu. Powodem była duża złożoność procesów zachodzących w silnikach pojazdów. Utworzenie warstwy teflonu na powierzchni cylindra powodowało zmianę topografii powierzchni, bardzo ważną dla rozprowadzania oleju i doprowadzania go do strefy tarcia. Kolejną cechą pokrycia powierzchni cylindra warstwą teflonu było zaburzenie odprowadzania ciepła przez ścianki cylindra, co prowadziło do przegrzewania się silnika i zwiększenia intensywności starzenia oleju silnikowego.

Stosowanie dodatków do olejów silnikowych, takich jak zdyspergowany teflon, nie znalazło akceptacji ani wytwórców olejów smarowych, ani producentów silników i samochodów. Brak akceptacji wynikał z ochrony interesu użytkowników pojazdów. Niemniej wytwórcy olejów smarowych: silnikowych i przekładniowych, prowadzą badania nad optymalizacją struktury chemicznej tych środków smarowych, tak aby w szerokim zakresie warunków eksploatacji pojazdów uzyskać zmniejszenie oporów tarcia.

Badania w tym obszarze skupione są na modyfikowaniu:

- Własności reologicznych olejów smarowych, odpowiedzialnych za smarowanie hydrodynamiczne - charakteryzujące się najniższą wartością współczynnika tarcia.

- Tzw. własności przeciwtarciowych obniżaniu współczynnika tarcia przy tarciu granicznym, przy którym współczynnik tarcia wykazuje znacznie większą wartość niż w warunkach smarowania hydrodynamicznego.

- Zdolności olejów smarowych do tworzenia trwałej warstwy granicznej i eliminacji lub znacznego ograniczenia bezpośredniego kontaktu powierzchni smarowanych elementów urządzeń, któremu towarzyszą największe opory tarcia.

Rezultatem tych badań było wprowadzenie i upowszechnienie olejów smarowych na bazach syntetycznych. Bazy syntetyczne, w przeciwieństwie do baz otrzymywanych z ropy naftowej, charakteryzują się wysoką wartością wskaźnika lepkości - im większa jest wartość wskaźnika lepkości, tym mniejszy jest wpływ temperatury na lepkość oleju. Dzięki temu możliwe było zoptymalizowanie własności reologicznych olejów silnikowych i przekładniowych, tak aby smarowanie hydrodynamiczne mogło występować w stosunkowo szerokim zakresie warunków pracy smarowanych węzłów tarcia.

Dwa kolejne z wyżej wymienionych obszary badań odnoszą się do tarcia granicznego i skupiają się na modyfikacji składu chemicznego tzw. pakietu dodatków uszlachetniających, zawierającego m.in. dodatki 


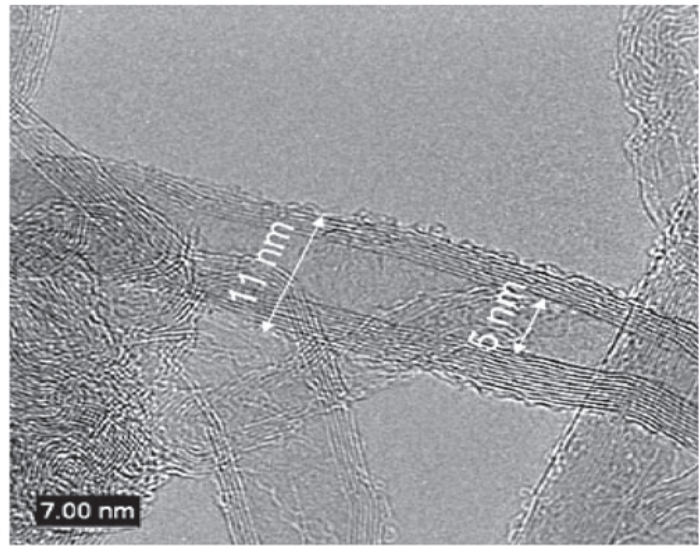

Rys. 3. Obraz z mikroskopu elektronowego i wymiary nanorurki węglowej (Holmberg et al. 2014)
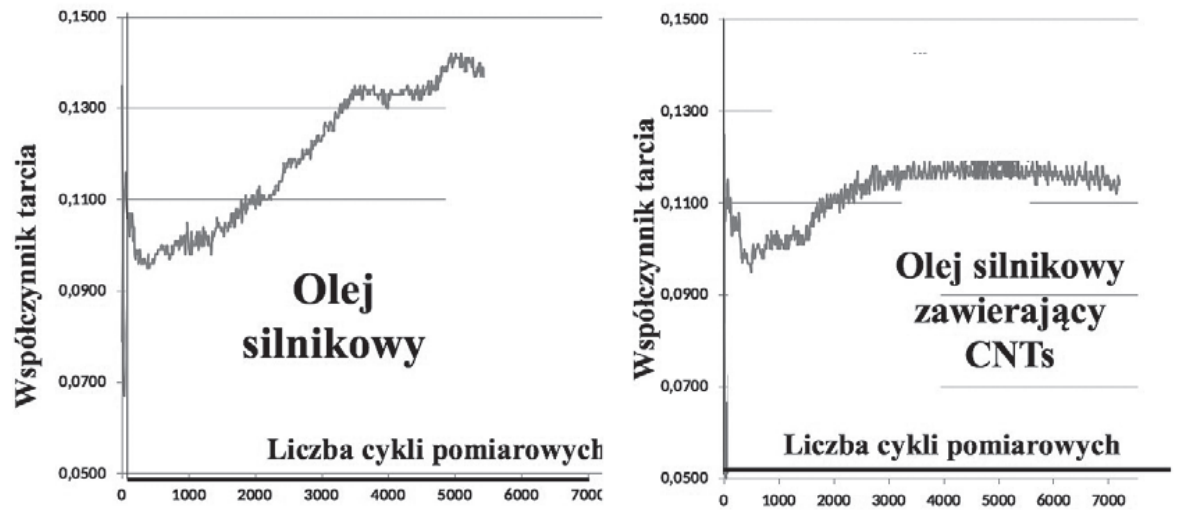

Rys. 4. Wyniki pomiarów oporów tarcia przy smarowaniu węzła tarcia tribometru HFRR olejem silnikowym i olejem silnikowym zawierającym CNTs

smarnościowe odpowiedzialne za tworzenie warstwy granicznej.

Przykładem mogą być, prowadzone przez autorów niniejszego artykułu, badania nad zastosowaniem tzw. nanorurek węglowych jako substancji zmniejszających opory tarcia w silniku tłokowym. Inspiracją były doniesienia literaturowe, m.in. (Chaveau et al. 2012), w tym współautora niniejszego artykułu (Kałużny et al. 2017). Przykładową strukturę nanorurek przedstawiono na rysunku 3.

Autorzy publikacji (Kałużny et al. 2017) przeprowadzili badania oporów tarcia w silniku tłokowym, napędzanym silnikiem elektrycznym. Silnik ten smarowany był handlowym olejem silnikowym, a następnie tym olejem zawierającym zdyspergowane nanorurki węglowe (CNTs). W czasie badań dokonywano pomiary oporów tarcia silnika przy dwóch prędkościach obrotowych: 1000 obr./min. i 2500 obr. min. W rezultacie badań stwierdzono, że wprowadzenie do oleju silnikowego CNTs spowodowało obniżenie oporów tarcia o 7\% przy prędkości 1000 obr./min. i 4\% przy prędkości 2500 obr./min.

Autorzy niniejszej publikacji przeprowadzili badania oleju silnikowego handlowego i zawierającego CNTs w zmodyfikowanym teście na tribometrze HFRR (ruch posuwisto-zwrotny, częstotliwość $50 \mathrm{~Hz}$, obciążenie $500 \mathrm{~g}$ ). W trakcie testu rejestrowano średnią wartość oporów tarcia. W rezultacie badań stwierdzono, że dodanie do oleju silnikowego CNTs spowodowało obniżenie oporów tarcia o około $5 \%$.

Przedstawione wyniki badań są wstępnymi i służą jedynie wskazaniu, że nanododatki 
do olejów smarowych, takie jak CNTs, mogą w przyszłości być jednym ze sposobów ograniczania oporów tarcia urządzeń wchodzących w skład środków transportu.

\section{Wnioski}

Przedstawione $\mathrm{w}$ artykule wyniki analizy danych o udziale tarcia w konsumpcji paliw silnikowych, a w konsekwencji emisji zanieczyszczeń powietrza atmosferycznego wskazują na potrzebę badań nad sposobami obniżenia oporów tarcia. Szczególne znaczenie ma ograniczenie oporów tarcia przekładni układu przenoszenia mocy w samochodach ciężarowych. Badania nad sposobami ograniczenia oporów tarcia przekładni układu przenoszenia mocy w samochodach ciężarowych są tym ważniejsze dla ochrony środowiska, że w samochodach ciężarowych powszechnie stosowane są silniki o ZS, zasilane są olejem napędowym. Silniki te wykazują szczególną skłonność do emisji takich zanieczyszczeń, jak WWA i cząstki stałe, a systemy oczyszczania spalin nie pozwalają na eliminację emisji tych zanieczyszczeń.

\section{Bibliografia}

Bochenek D. (red.) 2014, Ochrona Środowiska 2014. Informacje i opracowania statystyczne, Warszawa: Główny Urząd Statystyczny.

Chaveau, V., Mazuyer, D., Dassenoy, F. and Cayer-Barrioz, J., 2012, In situ film-forming and friction-reduction mechanisms for carbon-nanotube dispersions in lubrication, Tribology Letters (47)3, 467-480.

Holmberg K., Andersson P., Erdemir A., 2012, Global energy consumption due to friction in passenger cars, Tribology International 47, 221-234.

Holmberg K., Andersson P., Nylund N.O., Erdemir A., 2014, Global energy consumption due to friction in trucks and buses, Tribology International 78, 94-114.

Kacperczyk E, Rzymek B. (red.), 2015, Transport drogowy w Polsce w latach 2012 i 2013. Informacje i opracowania statystyczne; Warszawa: Główny Urząd Statystyczny.

Kałużny J., Merkisz-Guranowska A., Giersig M., Kempa K., 2017, Lubricating performance of carbon nanotubes in internal combustion engines - engine test results for CNT enriched oil, International Journal of Automotive Technology, Vol. 18, No. 6, 1047-1059.

\section{Selected issues of tribological processes in road transport influence on the state of the environment}

\section{Abstract}

This article investigates the issue of the environmental impact of car transport. This topic is discussed in the context of tribological processes, which result in increased fuel consumption and consequently increased emissions of exhaust gas components. Based on data found in the literature, the share of frictional resistance in the total fuel consumption of individual cars, trucks and buses was determined. Using statistical data for Poland, the effects of friction processes in individual vehicle groups on the annual $\mathrm{CO}_{2}$ emissions from transport vehicles were also determined. The final part of the paper presents the results of the preliminary research on the possibility of lowering the friction resistance in various friction nodes found in motor vehicles by introducing carbon nanomaterials into the lubricating oils.

\section{Keywords}

transport, fuels, exhaust gases, friction 